\title{
REINVENTING HABSBURG CUISINE IN TWENTY-FIRST CENTURY TRIESTE
}

\author{
Daša Ličen \\ Institute of Slovenian Ethnology \\ Research Centre of the Slovenian Academy of Sciences and Arts, Slovenia \\ e-mail:dasa.licen@zrc-sazu.si
}

\begin{abstract}
The article gives an overview of nostalgia for the Habsburg Empire in twenty-first century Trieste and recognizes it as a result of a broader shift in local identifications. More precisely, it traces nostalgia on the "typical" Triestine plates. The phenomenon that the author seeks to shed light on hence reveals itself as a metamorphosis of Trieste menus. The typical Italian pasta, pizza, and tiramisu have in the past decades been replaced by strudel, goulash, and sauerkraut, which supposedly reveal the true identity of this port city. Such dishes recall the flourishing times of the nineteenth century when Trieste reached its heyday as a part of the Habsburg Empire. Along these lines also the culinary enthusiasts prefer to emphasize the Habsburg or Central European character of the Triestine cuisine and promote it as culturally distinct from the traditional Italian one. The author argues that such nostalgic yearnings do not tell much about the past but rather about the present-day and perhaps also future Trieste.
\end{abstract}

Keywords: culinary nostalgia, food, Habsburg Empire, imperial nostalgia, Trieste

\section{INTRODUCTION}

In 1912, fourteen years after Empress Elisabeth of Austria had been stabbed to death in Geneva, ${ }^{1}$ a grand monument was erected in the city center of Trieste ${ }^{2}$, a city located in the northern extreme of the Adriatic. Among many monuments dedicated to Francis Joseph's spouse, commonly known as Sissi, which sprouted all across the Habsburg Monarchy, perhaps none had a shorter lifespan than the memorial instituted in the port city of Trieste, the imperial commercial hub. After World War I and the dissolution of the Habsburg Monarchy, Trieste became a part of the Kingdom of Italy, which unsurprisingly found it necessary to remove Sissi's monument. The Italian national state wanted to demolish every part of the cityscape that did not fit the new political frame and could remind the inhabitants of the former Habsburg rule. The twelve meters long tribute was stored for many decades and wholly forgotten until the 1980s, when debates 
about its restitution commenced. Yet, the initiative gained true strength only in 1991 when an association called Mitteleuropa (Germ. Central Europe) managed to collect as many as five thousand signatures in favor of the restoration of the monument. Six years and many discussions later, the monument was re-erected right in the city center, in front of the railway station.

The story of Sissi's monument, which I have portrayed more thoroughly elsewhere (Ličen 2017), does not seem to have much in common with the chosen title, at least not at first sight. However, taking the example of Sissi's monument, I attempt to demonstrate how Habsburg Trieste has been reimagined in the past three decades. The restitution of Sissi's monument reflects a revaluation of Trieste's Habsburg past, and serves as one of the many recently reawakened reminders of the vanished Habsburg grandeur. Historian Maura Hametz (2014: 136) described this nostalgic shift as follows: "[r] einvigorated by the blossoming of Central Europe after 1989, the city now looks to the 'ghosts' of its Habsburg past, articulated in its urban spaces, its culinary and arts culture, and its built environment".

I conducted my fieldwork in Trieste in 2016 and at the beginning of 2017. During fieldwork, I regularly visited all the typical culinary loci of Habsburg nostalgia, among them restaurants, bars, and cafés, and talked to their owners and local as well as foreign visitors. I gained additional in-depth insight into the topic by visiting gastronomic lectures, culinary workshops, cookbooks, and online debates on Habsburg Trieste. The focus of the present text is thus solely on the many Mitteleuropean flavors that are currently present in the city of Trieste, although Habsburg nostalgia could be explored in the whole region of Friuli Venezia Giulia (Baskar 2002: 71-95), which Trieste is a part of.

I initiate this article by briefly depicting Trieste's vivid past, then continue by offering some ethnographic insights into the culinary scene of Trieste - more precisely, by providing evidence of imperial nostalgia and identifying some foodstuffs and dishes that are supposedly typical of Trieste and Central Europe but non-existent in the rest of Italy, such as mustard, cren (horseradish), sauerkraut, sausages, goulash, apple strudel, krapfen (German for doughnuts), and other Trieste's favorites. When discussing the ethnographic accounts, I point out the absence of Slavic elements on these nostalgic plates, considering that Germanic associations seem to be preferred to Slavic ones. I subsequently provide a theoretical background to how food and nostalgia are interlaced, and emphasize that it is not about what nineteenth century Trieste really tasted like or how historically false, so to say, this popular narration is, but what it can tell us about this day and age. In view of food, the last part of my article expands on Pamela Ballinger's (2003) study of Trieste's nostalgic turn and Maura Hametz's (2014) analysis of how past is in service of present-day Trieste. 


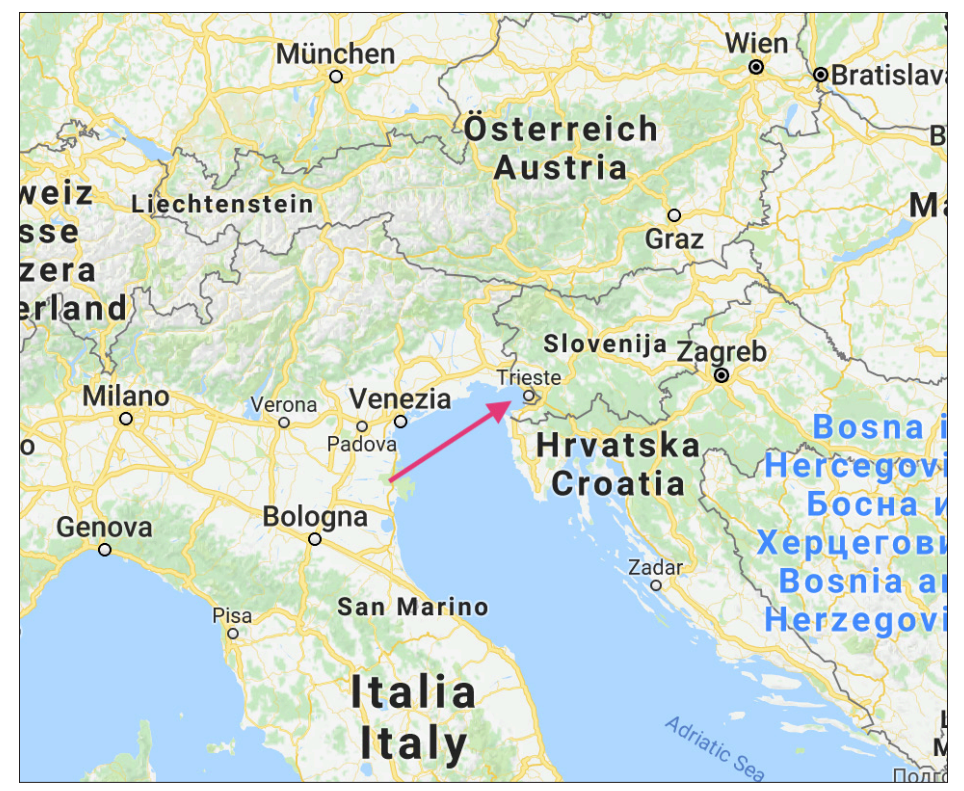

Figure 1. The port city of Trieste located in the very north of the Adriatic Sea (https: / / www.google.si/maps /@45.4292691,12.8923936,7z?hl=sl, last accessed on 2 February 2018).

In accordance with both, I claim that nostalgia can tell us considerably more about Trieste's present and future than about its supposedly splendid past, but also underscore why and how Slavic elements are hidden in this nostalgia. I am also conscious of the fact that the work I as an anthropologist or ethnologist do may itself be somehow nostalgic, but nonetheless expect this paper to form a part of the ongoing discussions on the topic. The present ethnography based article hence reveals the nostalgia for the Habsburg Empire, yet investigates its circumstances only in the realm of food. Moreover, it seeks to give an overview of Trieste's recent culinary trends in order to have a look beyond nostalgia and understand its role in contemporary political currents.

\section{TRIESTE'S PAST AND PRESENT}

Trieste came under the control of the House of Habsburg in 1382, but grew from a small fishing town to an influential imperial hub only after 1719, when Charles VI granted the city the status of a free port, the groundwork for Trieste's success. During the eighteenth and nineteenth centuries, Trieste experienced a period of prosperity thanks to its free port privileges and the development of 
a thriving shipping business that made it one of the most important European ports and certainly the biggest one within the Habsburg Empire (since 1867 Austria-Hungary). Not only its business, but also its population grew immensely. Trieste's population increased from about 6,000 at the beginning of the eighteenth century to as many as 240,000 inhabitants in 1914 (Kappus 1997: 172). Trieste's economic existence attracted individuals and families from all over Europe and beyond (Kalc 2008). As a result, the physiognomy of the city changed considerably. The busy port city of Trieste thus reached its highlight under the rule of Francis Joseph as the monarchy's vital outlet to the sea. Images of the nineteenth century Trieste are precisely the ones the current popular narratives mythologize, praise, and denote as cosmopolitan. Cultural heterogeneity is central to Habsburg nostalgia, to which I return below.

The nineteenth century Trieste enabled a rather peaceful cohabitation of very different people adhering to various, also non-Catholic religions, and speaking several languages. So much so that Dominique Kirchner Reill (2012: 20) talks about an active "maritime polyglotism", but all this changed in the decades after 1848, and especially from the 1860s onwards, when nationalism started gaining an increasingly important role (Cattaruzza 1992: 191; Millo 2007: 74). The seeming harmony of Trieste's heterogeneous population began to fade while pressing ethnic issues were emerging. More accurately, two national movements aimed to, at least symbolically, conquer the city of Trieste. So much so that until the outburst of World War I Trieste was, for the most part, polarized into Italian and Slovene (Kappus 1997: 176; Verginella 2009: 101). The conflict between Slovenians and Italians had indeed been vigorous but reached its climax only after the Great War, when Trieste was incorporated into the Kingdom of Italy and not much of its once dominating cultural diversity had a chance to survive. In addition to that, the collapse of the Austro-Hungarian Empire and Trieste's annexation to Italy led to a decline in the town's economic importance. The links with Central Europe were severed and the city lost its strategic and commercial influence. Trieste went from being "città fedelissima" ("most loyal') to "Trieste italianissima" ('most Italian') and was now nothing more than a "second-rank Italian seaport" (Griffante 2015: 19).

The interwar fascist period represents the pinnacle of Italian nationalism that was persecuting and criminalizing Slovene population (Verginella 2016: 711-712), but also in general annihilating any visible signs of ethnic otherness in Trieste's cityscape (Baskar 2002: 71; Griffante 2015: 23; Klabjan 2015: 125). During World War II, Trieste was conquered by Germans in 1943, by Yugoslav partisans in 1945, and only 40 days later taken over by the allied forces. In 1947, the allied military government established the Free Territory of Trieste, which lasted only until 1954, when Trieste was proclaimed to be a part of Italy again. 
National sentiments certainly started to weaken in the second half of the twentieth century, especially from the 1980s onwards, when Trieste started to long for the fame it had enjoyed before the outbreak of World War I. This is when yearnings for the times when Trieste supposedly existed as an idyllic cosmopolitan city, embraced in the safe arms of the emperor, materialized. In other words, from the 1980s onwards, the nationalist past was pushed aside and above all nineteenth century history, or rather a certain image of that period, came to the fore (Kappus 1997: 170; Baskar 2002: 83-87; Ballinger 2003; Waley 2009). From then on, Habsburg, Austrian, Central European or Mitteleuropean began to be preferred over Italian, which, however, should not tempt us into thinking that nationalism completely vanished from the city (to which I return later), nor into forgetting that Habsburg nostalgia does not necessarily mean exactly the same thing to different people (Baskar 2002: 76-93). Nonetheless, the nostalgia for the city's heyday and its pluri-ethnic Central European fabric seems to have been shaping Trieste's social and cultural microcosm in a renewed manner. Habsburg wistfulness can fascinatingly be discerned also in the field of food, which the following pages seek to shed a light on.

\section{EATING THE EMPIRE}

In the center of Trieste there is a small restaurant called Buffet da Pepi. When one enters the restaurant, he or she quickly notices the smell of various kinds of pork dishes, as well as the supposedly nineteenth century imagery and furnishing giving the place, to put in plain words, a specific feeling. One of their pleased visitors described her journey into the culinary world of "authentic" Trieste as an "excursion to Austria-Hungary". The only thing that makes the visitor suspect he or she is in the twenty-first century are various certificates hanging on the walls, which further confirm the supposed authenticity of this place. The current owner told me that the restaurant was first established at the end of the nineteenth century and had remained "the same" since then. Although they had recently expanded to a certain extent and added another room, they had reproduced the added furnishings so they looked old and came across as "genuini" ('genuine').

What they serve at $\mathrm{Da} P e p i$, also known as Pepi Sciavo, ${ }^{3}$ are generally different kinds of pork, either freshly cooked or preserved, but always in a rather simple manner. Their plates are nonetheless adored - as someone stated on the Buffet's Facebook profile, "best pork from Vorarlberg to Bukovina" (in Triestine dialect " "la miglior porzina da vorarlberg a bukovina"). Cooked pork is here served with sauerkraut, to which Triestines proudly refer with the term capuzi $i^{5}$ 


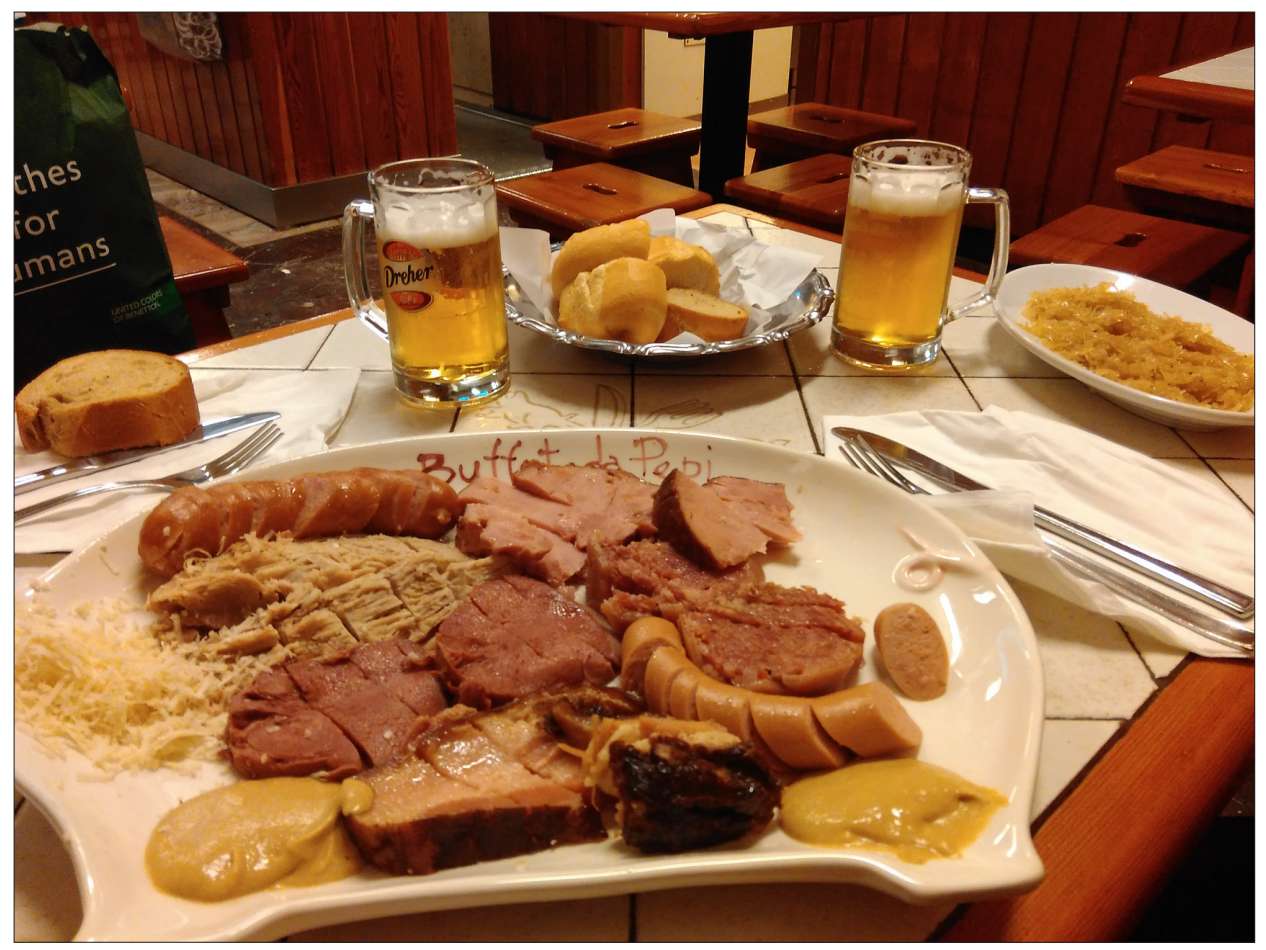

Figure 2. A plate of Buffet da Pepi’s meaty delicacies. Photograph by Daša Ličen 2016.

(and not with the standard Italian expression crauti), mustard served from big ceramic jars, grated horseradish or cren, and beer served in a mug (Fig. 2). The dessert they serve further reinforces their Central European character - it is the beloved apple strudel sprinkled with powdered sugar. Carnivore mood is definitely compulsory if one wants to enjoy these meat delicacies, but one can get a taste of the empire also by visiting many less "meaty" local sites. Most Triestines usually suggest Buffet da Pepi first when asked for recommendations though.

Also the hearty jota soup served in many restaurants in Trieste enables one to taste the imperial times when Trieste was a blooming port city in the glorious monarchy. Jota is made out of fermented cabbage or capuzi, beans, smoked pork, and potatoes. According to a very popular local Facebook page with a telling name Vota Franz Josef (Vote Francis Joseph), ${ }^{6}$ Europe can be divided into two poles: the north-eastern, continental part with sauerkraut as a steady part of its diet, and the south-western, Mediterranean part with tomato as a key ingredient. The map that the Vote Francis Joseph site published in September 2016 (Fig. 3), states that also in the title "Home is where sauerkraut is" (in Triestine 


\section{DOVE XE CAPUZI XE CASA}

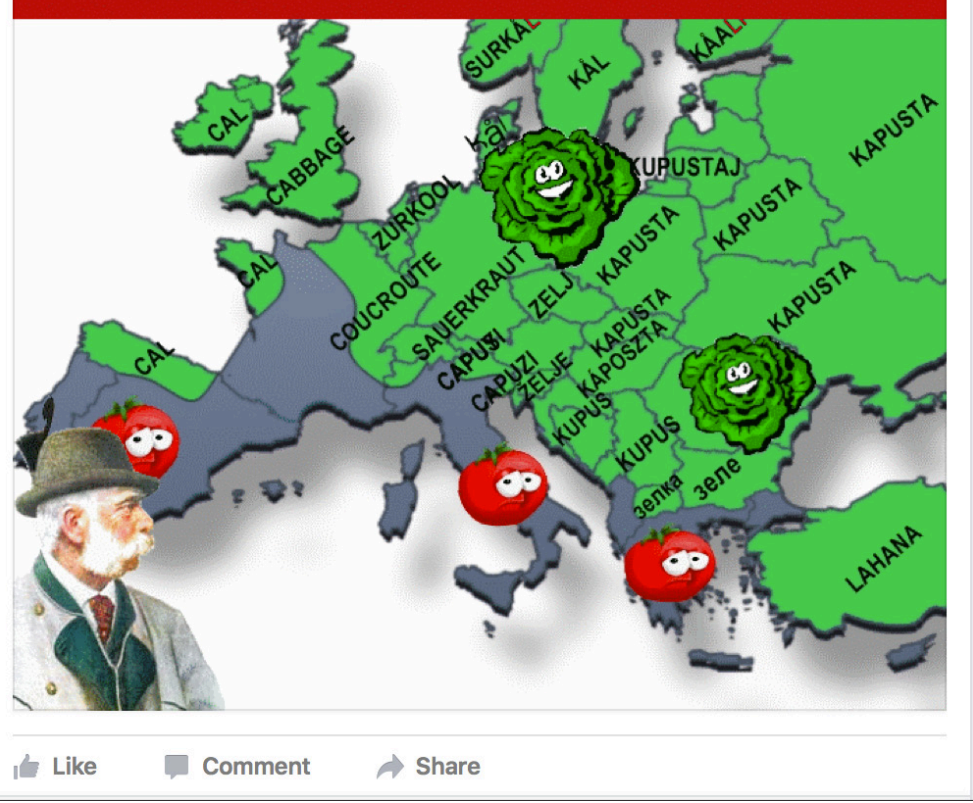

Figure 3. The map titled "Home is where sauerkraut is" posted by the Facebook page Vota Franz Josef (Vote Francis Joseph) in September 2016 (https: / / www.facebook. com/VotaFranzJosef/photos/a.197855977026304.67292.193521680793067/9611 32497365311 / ?type=3\&theater, last accessed on 2 February 2018).

dialect, "Dove xe capuzi xe casa"). In addition, Francis Joseph's profile inserted in the bottom left corner of the map is contently eyeballing the curious map. On this map, Trieste is depicted as a part of the north-eastern unit, thus apparently consuming sauerkraut rather than tomatoes. Sauerkraut and various dishes made out of it have since the end of the Cold War been emblematic symbols of Trieste and unmistakably represented one of the flavors and textures of Central Europe dissimilar to the dishes found in the rest of Italy.

Similarly, many restaurant owners proudly explain and try to demonstrate how their roots go all the way to imperial times. They, above all, like to connect their traditions in one way or another to Vienna. If, for instance, their chef or cook once worked in Vienna or attended a Viennese culinary school, this quality is surely fostered and is potentially bringing more guests to the restaurant. 
By the same token, links to the former empire are alluded to through creative restaurant, café or bar names, such as Sissi Bar, Buffet Impero (Buffet Empire) or Theresia Mittel Bistrot. In passing, the latter is even equipped with what Trieste's municipal promotional webpage Discover Trieste describes as "Viennese style chairs". ${ }^{7}$

However, not only the bars and restaurants, but also many dishes recall the imperial past by their particular names. I already touched upon sauerkraut or capuzi, but palacinka ${ }^{8}$, thin and round flat cake made from eggs, milk, flour, butter, and salt, is noteworthy too. This thin variety of pancake is regular in Eastern and Central Europe, but called slightly differently in every language. When in 2000 Maura Hametz (2005: 167) interviewed Mario Suban of the Antica Trattoria Suban, another Triestine restaurant located on top of the so-called scale of authenticity, he claimed that "palacinche (pl. of palacincha) are palacinche. They are not crepes nor are they English pancakes or omelets". According to Mario Suban, palacinka is a typical Triestine dish, a result of Central European influences, hence appearing as a genuine indicator of "Central-Europeanness" in the whole area of the former monarchy.

The emphasis is thus constantly on the Habsburg or Mitteleuropean character of the Triestine cuisine, which is promoted as culturally distinctive from the Italian one. The culinary enthusiasts promote dishes that stress Trieste's Austrian or, on occasion, even more exotic Hungarian origins and its belonging to Central Europe, but let me support this statement with further examples.

Fin-de-siècle cafés are very informative examples in this regard. According to the eminent historian Pieter Judson (2016: 346-347), coffee houses were, along with some other architectural but also general cultural components, a strong part of the visual power of the Habsburg Empire, and to some extent have remained so in the area once under Habsburg rule. Vienna is considered to be the capital of refined Kafeehäuser, places of intellectual encounters normally associated with highbrow individuals such as Stefan Zweig or Sigmund Freud, but similar cafés have been (re-)gaining in popularity also in Trieste. The ones originating more than a century ago are always found on the touristy "must do" lists that suggest the visitors to have a bite of the famous Sacher or Linzertorte cakes. As Hametz notes (2014: 146), such cafés willfully endorse associations with Habsburg past. Moreover, it is well known that Claudio Magris, a Triestine writer renowned for his nostalgic oeuvre evoking multicultural Central European history and its legacy, likes to have his coffee, read newspapers or merely linger in Caffé San Marco (Ballinger 2003: 96). These fashionable cafés, now commonly described as historical, hence still or perhaps again serve as meeting points of the contemporary intelligentsia. 
It is certainly true that between Vienna and Trieste, two crucial hubs of the long-gone empire, many parallels exist, but also that many amongst them have recently been re-drawn. A few Triestine pastry shops also try to come across as places where time stands still. The owners of La Bomboniera, for example, present their pastry shop as "typically Austro-Hungarian", and state that their roots go all the way to 1836, when the Eppinger family employed a Hungarian pastry chef in their bakery. ${ }^{9}$ La Bomboniera's interior is designed in Art Nouveau style, but the working area is supposed to be more than a century old too. According to what they claim on their webpage, century-old machines are still used to produce cakes, such as the layered Dobostorte, Rigojansci, Pischinger, Putizza, Presnitz or again Sacher and Linzertorte, all evoking nostalgia for the Habsburg rule.

\section{ON SLAVIC TASTES}

According to the historian Larry Wolff (1994: 360), already during the nineteenth century the category 'Slav' was negatively connoted by those who considered themselves to be Italian. In the decades before World War I, the Slavs were increasingly seen as inferior (Sluga 2001: 18-25), but even more so in the interwar period, when Slovenians in Trieste were subjected to violent fascist policies (ibid.: 39-63). In the decades after World War II, Slovenians were indeed granted minority rights but were still perceived as a latent Yugoslav "Trojan horse". The state of affairs for Slovenians living in Trieste and its surroundings generally improved in the past decades (Bajc 2017: 33-37). However, negative connotations related to anything Slavic - be it Slovene, Croatian, Serbian or other - persist. Such status quo could be the reason why Slavic elements are barely present in the nostalgic culinary discourse I am analyzing. It could, however, be that the reasons lie elsewhere. I would hereby also like to claim that I am conscious of the fact that being a Slovenian myself influences my interpretation of this issue, yet I strive to, as much as possible, detach my own national belonging from the present analysis.

Already in his 2002 monograph, Bojan Baskar (2002: 86-89) mentioned that Slovenians were not very nostalgic for the former Habsburg Empire. My fieldwork, nevertheless, did not give me an impression that Slovenians would not praise the days of Trieste's belonging to the Habsburg Empire, nor do they seem to represent the main stakeholders in what Baskar calls "Mitteleuropean discourse". Baskar (ibid.: 90) also pointed out that Slovenians are somewhat missing from this nostalgia. Annalisa Colombino (2009: 293) in her excellent paper on marketing Trieste's multiculturalism, which essentially stresses the same characteristics as the nostalgic narrative I am scrutinizing in this paper, 
noticed that the representation of Trieste's multi-ethnic character has been highly sanitized and selective. According to her, multiculturalism is constructed in a way that excludes certain groups of inhabitants, along with the Chinese, Albanians, and others, also Serbians and Slovenians. I, too, support this claim by noticing that Slavic elements, although representing a steady segment of Trieste's social realm in the times of the empire, are, when it comes to evoking Habsburg tastes, regularly forgotten or at least camouflaged.

Today the Triestine cuisine is understood as a Central European mixture by a large number of the inhabitants of this port city and, above all, by the individuals who use their gastronomic expertise to influence the public opinion on what authentic Triestine food is - a mixture that is unquestionably greater than the nation, especially the Italian one. Also, according to Elke Kappus (1997: 170) and Maura Hametz (2014: 144), Habsburg nostalgia is seemingly oblivious to ethno-nationalist differences. The idea behind the culinary nostalgia I am analyzing is that fragments from all over the former empire shape a Central European mixture that has developed a character of its own. It is not surprising that culinary traditions from places like Brody in Galicia are not part of the culinary image Trieste is promoting today; yet, it is peculiar that Slovenians, who have at least from the nineteenth century onwards been a regular and numerous segment of Trieste's social realm, do not have a voice in this historical narration. Even if we look beyond nations and think of the Slavs as a supranational category, they are more or less an ignored part of the Habsburg nostalgia.

The nostalgic menu did not come down from heaven as a well-defined list of dishes that unmistakably form the Triestine cuisine; quite the contrary - influential gourmet authorities construct this image and carefully choose what fits in. Along these lines, it is then of no surprise that Slavic elements are curbed, while Austrian, Hungarian, and especially German ones are stressed, although the latter might, in light of the bitter twentieth century rapports between Trieste and Germans, come across as surprising (Hametz 2014: 144). Hungarian bits of the Triestine puzzle are especially curious, because, in contrast to Slovenians or Serbians, there were barely any Hungarians in the nineteenth century Trieste. I assume Hungarians were and have remained far enough from Trieste to come across as mysterious and exotic. The interest in the signs of Hungarian origin is noteworthy also because the monarchy was, as a result of the compromise in 1867, known as Austria-Hungary, a dual monarchy in which the Kingdom of Hungary became equal to the Austrian Empire.

One of the tasty cakes from Trieste, which, according to my informants, is absolutely typical, presents a very revealing case. Presnitz is a part of a wider family of strudels and rolled up cakes prepared with a filling made from different 
kinds of nuts, raisins, dark chocolate, and rum (depending on the recipe). According to Hametz (2014: 148), presnitz cake "attests to the continuing resonance and even romance of Habsburg life and tastes in the Adriatic city". Following the prevalent version of the local myth, this cake was born in the nineteenth century, when the Habsburg Empress Elisabeth (Sissi) visited Trieste and awarded what was called Preis Prinzessin to the creator of this novel dessert. As a consequence, the rolled cake got its name after the prize. But the etymological roots of the word presnitz are in fact clearly Slavic, meaning presnec or unleavened, as this kind of pastry is used for its preparation. Despite that, presnitz is spelled with ' $t z$ ' characteristic of German at the end, and not the Slovenian ' $c$ ' that actually sounds just the same. Hence, not only the abovementioned myth, but also the spelling links presnitz to German imperial culture.

To sum up, the promoters of the nostalgic cuisine I have put under the microscope prefer German associations over Slavic ones. The previously mentioned palacinka is, for instance, often spelled like in German, palatschinka, although it could easily be written in Italian, Slav, or some other way and not necessarily German. Although it seems like the assortment of Triestine foods simply exists in the eternally kaisertreu (loyal to the emperor) Trieste, it is not the case. The Triestines - the owners of restaurants and cookbook writers - select what is considered to be authentic Triestine food and what is not. Their intention is not to falsify the past, but rather adapt it to their needs. As was suggested earlier, the menu of Triestine dishes - even though clearly containing many Slavic elements - is constructed in a fashion that emphasizes the features of the German-speaking area of Central Europe and ignores the Slavic ones. Below I dwell upon why German cultural references rank higher in this nostalgic discourse.

\section{GUSTATORY NOSTALGIA}

According to Michael Pickering and Emily Keightley (2006: 920), nostalgia, although always manifesting itself in a variety of ways and hard to simplify, is a "longing for what is lacking in a changed present ... a yearning for what is now unattainable, simply because of the irreversibility of time". On the one hand, nostalgia can be a very personal experience, and a cultural phenomenon on the other. Arjun Appadurai (1996: 78) has referred to the latter as "armchair nostalgia". It is a feeling of loss of something one has never experienced, like in the case of food-centered nostalgia in Trieste. However, for the purposes of the present article it is not necessary to dwell on the distinction between the two kinds of nostalgia. 
Nostalgia has often been attacked as a sentimental and falsifying practice that instrumentalizes the past (Angé \& Berliner 2014: 4). Yet, as previously suggested, in this article nostalgia's historical accuracy is not under discussion. In other words, I am not interested in what nineteenth century Triestines really ate and to what extent the current culinary trends correspond to that. On the contrary, I seek to uncover what nostalgia for the Habsburg Empire, which in the last three decades has been one of the focal points of triestinità, can tell us about the contemporary social configurations. I consider nostalgic sentiments to be very interesting, regardless of whether they are yearning for a past that once existed or not, so irrespective of their being a result of true experiences, completely imagined or anything in between.

In the past, a naive anthropologist or ethnologist would perhaps try to "illuminate" his or her field interlocutors by explaining that they cannot be nostalgic for a nineteenth century dish they themselves have never tasted or that popular historical cafés they currently long for were in the early twentieth century hardly islets of cosmopolitanism and open-mindedness, but often irredentist nests. A plaque, for instance, commemorates early enthusiasts for "free Italy" that were meeting in Caffé Tommaseo, also known as the oldest café in Trieste. ${ }^{10}$ However, patronizing and deconstructing nostalgia would not contribute to knowing why people do what they do. Underlining the absence of Slavic elements was also not meant to criticize the way this nostalgia is constructed in relation to the past, but should rather be understood as a means to point out it is perhaps not a coincidence that some parts of the former empire are highlighted while others are veiled.

Nostalgia can take very different forms and food is one of the ways it materializes. Already Marcel Proust in his prominent work titled In Search of Lost Time linked memory with the gustatory dimension. The taste of a madeleine dipped in a cup of lime flower tea brought him back to his childhood in Combray. Food as a powerful means of experiencing nostalgia was addressed also by anthropologist David Sutton in his work on intersections between food and memory, Remembrance of Repasts (2001). He concentrated specifically on gustatory nostalgia, explaining the capacity smelling and tasting have in crafting memories, to which Tulasi Srinivas (2013 [1997]), in her study of the radical change in food consumption in India, refers with the term "gastro nostalgia". According to her, for Indians food can symbolize the long-lost utopian ideals (ibid.: 369). Along the same lines, food serves as a vehicle for recollecting memories of the "golden age" also in Trieste where, in the words of one of my interlocutors, "one can get a taste of the Habsburg Empire".

Apropos, nostalgia manifests itself also as an influential marketing strategy. In late capitalist consumerism, the "lubricant of nostalgia" (Appadurai 1996: 
76) is frequently applied to consumer goods, as is the case with yet another "typically Triestine" rolled cake with, at least etymologically, Slavic roots. Triestine putizza comes from Slovene or Slavic potica, which derives from povitica, denoting rolled-up dough. Putizza represents a fine example of commodified authenticity, which is sold in chain supermarkets, such as the (ill-)reputed Eataly, where it - neatly packed - represents a home-made, traditional, local and, most of all, Habsburg product. Such a putizza gives an impression of something lost in time and can, because of its patina, reach substantially higher market value than - at least technically - similar products.

\section{NOSTALGIC FOR THE FUTURE}

In this chapter, I draw on what the historians Pamela Ballinger (2003) and Maura Hametz (2014) wrote on the subject of present-day nostalgia for the Habsburg Trieste, and discuss it in light of my own ethnographic study of the culinary dimension of Habsburg nostalgia. The central idea that I dwell on here is that nostalgia is, in point of fact, not a retreat to the past, but an aspiration for the future. Put in a more precise way, contemporary Triestines are maybe not nostalgic for Trieste as a nineteenth century emporium, but desire stable if not blooming twenty-first century economic and cultural circumstances. Ballinger and Hametz were not the first to notice the links between imperial nostalgia and contemporary visions of development in Trieste; Bojan Baskar (2002: 84), for instance, touched upon this already in his 2002 monograph, but did not explore the question in more depth.

In her article, Pamela Ballinger (2003) reviewed three contemporary books representing imperial nostalgia for the Habsburg Trieste. She was critical to how the nostalgic narrative is constructed in relation to the city's nineteenth century actual past. According to her, the mythicized images of Trieste acquired new potency in the post-Cold War era, when Trieste became universally described as "cosmopolitan", "hybrid" or a "melting pot". As the Iron Curtain fell, European intellectuals on both sides remembered Mitteleuropa, not least in Italy. For many the concept of Central Europe, which, to be honest, deserves a study of its own, served as a way to escape from communism or Eastern Europe as such; for others Central Europe represented a means for entering Western Europe. Ballinger (ibid.: 97), however, stresses that after the fall of the Iron Curtain new possibilities for reattaching to Central Europe opened and attempts to revive Trieste's dormant port arose also in Trieste. The invocations of Mitteleuropa thus reveal genuine political stakes. In other words, Ballinger talks of prospective nostalgia because current mythologizing uncovers relationships 
that exist between the past, the present, and the future. Habsburg nostalgia is hence carrying a politics of the future with it.

Maura Hametz (2014) touched upon the selective remembrance of Trieste's history in a very similar way. According to her, historic Habsburg tastes have been reemerging from the 1990s onwards. Her first important emphasis is that Habsburg nostalgia aims to transcend local ethnic and nationalist conflicts that have been burdening the city for decades. As she put it, Habsburg nostalgia "provides a means to transcend the hostility and trauma associated with the decades of ethnic and nationalist conflict and violence that have marred civic, regional, and national relations in the northern Adriatic territory" (ibid.: 134). The second vital argument Hametz made is that "Habsburg nostalgia provides a vehicle to reconcile the city's Central European past with its position on the geographical periphery of Italy and western Europe" and continued with saying, "[i]t presents opportunities for development and association beyond the confines of Italy, a state that Triestines, rightly or wrongly, see as neglectful of their needs and ignorant of their particular situation" (ibid.: 131-132). Thus, by the words of Hametz (ibid.: 135), nostalgia is not a "simple glorification of the past but a means of imagining the future and reconceiving cosmopolitanness to re-position the border city and craft its political future".

According to both authors, Trieste was redefined after the fall of the Iron Curtain. The many nuances of nostalgia should therefore be understood as yearnings for the imagined imperial glories. In accord with both authors, also my ethnographic research leads me to believe that Habsburg nostalgia grew out of the inhabitants' contemporary dissatisfaction with Trieste's economic and political role as a provincial Italian town. Taking economic struggles into consideration, one can then grasp why Slavic associations tend to be neglected and Germanic ones accentuated. As Maura Hametz (2014: 143) points out, "ties to the Habsburg and the Germanic past were reinvented in light of the increasing integration of Europe and the expansion of the European Community in which Germany took a leading role". As nostalgia, on the one hand, lays emphasis on certain historical aspects, it has the power to facilitate forgetting on the other (Angé \& Berliner 2014: 10).

But štrudel (strudel), potica (putizza) or presnec (presnitz) have been overlooked not only on the grounds of economic interests, but also as a result of decades if not centuries long animosity towards Slavs, especially Slovenians, in the city of Trieste. For many Italians Slovenians have been representing a perilous threat, to which occasional claims that Trieste is categorically Slovene only contribute. I want to point out that even though Habsburg nostalgia at first sight strives to unite the city of Trieste into a tolerant whole, older clashes persist. Deep-rooted issues of nationalism continue to survive and, 
even if rather dormant today, carry the risk of re-arising. National sentiments then probably represent the other part of the answer to why Slavic elements of Trieste's culinary past are still somewhat stifled.

\section{CONCLUSION}

Food is one of the cornerstones of our ever-shifting identities, so such tensions as choosing what is Triestine food and what it is not expose much more than what is visible at first glance. In the case of Trieste, nostalgia serves political purposes to put some distance between the city of Trieste and Italy. It brings Trieste closer to Central Europe, but foremost to the Central European economy. Strudel, goulash, jota, sausages, and other Habsburg staple dishes surpass their mere belly filling dimension and bring to light modern-day hopes for Trieste's revitalization in the united Central Europe.

It is then not astonishing that Slovene or Slavic connoted dishes are commonly unseen, at least in comparison to Hungary evoking Dobostorte, but even more when set side by side with plates suggesting German origins, such as Kaiserschmarren (shredded palacinka) served in the "tradizionalissimo" ("most traditional') Vecio Buffet Marascutti from 1914. This legendary restaurant also serves a dish called Ljubljanska (stuffed breaded and fried cutlet). This plate's name indicates that historical roots of Ljubljanska can be traced to Ljubljana, the nowadays capital of Slovenia that was once an imperial town too. Marascutti's menu may thus give an impression that things in Trieste are not black and white, and that nostalgic tendencies are at times more broadminded than the present article has put forward. Nevertheless, my fieldwork led me to argue that imperial nostalgia has played an active role in the last decades of Trieste's past and that in such reminiscences Slavic elements are most often forgotten. After all, on the Buffet Marascutti's menu Ljubljanska is denoted literally as "(ham-and-cheese) stuffed schnitzels", ${ }^{11}$ describing cutlets in neither English nor Italian or Slovenian terms, but a variation of German.

Habsburg nostalgia, be it materialized in the form of food and food-related things or in other bits and pieces of Trieste's cityscape, is an attempt to return the past fame and success to this port city. Recognizing nostalgia's general importance is crucial, but what it will bring, if anything besides Austrian tourists, is still unclear. To further complicate the picture, it is entirely possible that, before causing any political outcomes, Trieste will transform its image again. The identities of places are, after all, as dynamic and unfixed as any other identities. 


\section{ACKNOWLEDGMENTS}

This research would not have been possible without the financial support from the Slovenian Research Agency. I also gratefully acknowledge the comments of Blaž Bajič, Vanja Huzjan, Saša Poljak Istenič, and Barbara Turk Niskač.

\section{NOTES}

1 She was assassinated on September 10, 1898, in Geneva, by a Paris-born Italian anarchist Luigi Lucheni (1873-1910).

2 All place names carry at least indirect political connotations, from which I cannot completely escape in this article. It would be politically as well as historically most correct to talk of Trst/Triest/Trieste, not necessarily in that order, but I am, for the sake of simplicity, sticking only to Trieste, which I consider to be the name Trieste is today most known for.

3 Sciavo is otherwise a disparaging term, a combination of schiavo (slave) and Slavo (Slav). Although the term sciavo nowadays carries very bad connotations and is, as such, considered to be inappropriate, it is unproblematized as a historical place name and regularly used by the locals in this context. It derives from the name of one of Buffet's former owners Pepi, who was Slovenian. For more details see Buffet da Pepi's website: http://www.buffetdapepi.it/storia.php, last accessed on 23 January 2018.

4 Triestine dialect is an important aspect of this nostalgic discourse. By using this particular dialect, Trieste establishes itself as different from other parts of Italy. Many Habsburg aficionados therefore prefer to avoid standard Italian and use the Triestine dialect enriched with many Germanic terms.

5 Often written also as capuzzi.

${ }^{6}$ SeeVotaFranzJosef s Facebook profile athttps://www.facebook.com/VotaFranzJosef/?ref=br_ rs, last accessed on 23 January 2018.

7 See the homepage at http://www.discover-trieste.it/code/18533/Theresia-mittel-bistrot, last accessed on 23 January 2018.

8 At times spelled also as palacinca, palatschinka or palačinka, and etymologically deriving from the Latin placenta (a flat cake).

9 See La Bomboniera's webpage at http://www.pasticcerialabomboniera.com/storia.html, last accessed on 23 January 2018.

${ }^{10} \mathrm{I}$ am fully aware that a single place can represent a lieu de mémoire for different groups of people. Caffé Tommaseo can thus be significant to those nostalgic for the Habsburg Empire as well as for those yearning for the purely Italian Trieste.

${ }^{11}$ See http://www.buffetmarascutti.it/menu\%20marascutti.pdf, last accessed on 23 January 2018. 


\section{REFERENCES}

Angé, Olivia \& Berliner, David 2014. Introduction: Anthropology of Nostalgia Anthropology as Nostalgia. In: Olivia Angé \& David Berliner (eds.) Anthropology and Nostalgia. New York \& Oxford: Berghahn Books, pp. 1-15.

Appadurai, Arjun 1996. Modernity at Large: Cultural Dimensions of Globalization. Minneapolis \& London: University of Minnesota Press.

Bajc, Gorazd 2017. Med jasnim in oblačnim: Kratek oris zgodovine Slovencev v Italiji. [Between Clear and Cloudy: A Short History of Slovenes in Italy.] In: Norina Bogatec \& Zaira Vidau (eds.) Skupnost v središču Evrope: Slovenci v Italiji od padca Berlinskega zidu do izzivov tretjega tisočletja. [Community in Europe's Center: Slovenes in Italy Since the Fall of the Berlin Wall to the Challenges in the Third Millennium.] Trst: ZTT, pp. 31-39.

Ballinger, Pamela 2003. Imperial Nostalgia: Mythologizing Habsburg Trieste. Journal of Modern Italian Studies, Vol. 8, No. 1, pp. 84-101. http://dx.doi.org/10.1080/1 354571022000036263.

Baskar, Bojan 2002. Dvoumni Mediteran: Študije o regionalnem prekrivanju na vzhodnojadranskem območju. [The Ambiguous Mediterranean: Studies on Regional Overlapping in the Eastern Adriatic.] Koper: ZDJP.

Cattaruzza, Marina 1992. Slovenes and Italians in Trieste, 1850-1914. In: Max Engman (ed.) Ethnic Identity in Urban Europe. Comparative Studies on Governments and Non-Dominant Ethnic Groups in Europe, 1850-1940. Dartmouth: New York University Press, pp. 189-219.

Colombino, Annalisa 2009. Multiculturalism and Time in Trieste: Place-Marketing Images and Residents' Perceptions of a Multicultural City. Social \& Cultural Geography, Vol. 10, No. 3, pp. 279-297. http://dx.doi.org/10.1080/14649360902756622.

Griffante, Andrea 2015. Between Empire and Nation State: Urban Space and Conflicting Memories in Trieste (19th - Early 20th Century). Journal of Architecture and Urbanism, Vol. 39, No. 1, pp. 17-27. https://doi.org/10.3846/20297955.2015.10 31441.

Hametz, Maura 2005. Making Trieste Italian, 1918-1954. Woodbridge: Boydell Press.

Hametz, Maura 2014. Presnitz in the Piazza: Habsburg Nostalgia in Trieste. Journal of Austrian Studies, Vol. 47, No. 2, pp. 131-154. http://dx.doi.org/10.1353/ oas.2014.0029.

Judson, Pieter M. 2016. The Habsburg Empire: A New History. Cambridge \& London: The Belknap Press of Harvard University Press.

Kalc, Aleksej 2008. Tržaško prebivalstvo v 18. stoletju: priseljevanje kot gibalo demografske rasti in družbenih sprememb. [Trieste's Population in the 18th Century: Immigration as an Impetus of Demographic and Social Changes.] Koper: Založba Annales.

Kappus, Elke-Nicole 1997. Eine Zukunft für Triest oder über die Rekontextualisierung der Geschichte / Prihodnost za Trst ali o rekontekstualizaciji zgodovine. Etnolog, Vol. 7, pp. 149-180. Available at https://www.etno-muzej.si/sl/etnolog/ etnolog-7-1997, last accessed on 23 January 2018. 
Kirchner Reill, Dominique 2012. Nationalists Who Feared the Nation: Adriatic MultiNationalism in Habsburg Dalmatia, Trieste, and Venice. Stanford, CA: Stanford University Press.

Klabjan, Borut 2015. Nacionalizacija kulturne krajine severnega Jadrana na začetku 20. stoletja: primer Verdijevega spomenika v Trstu. [The Nationalization of the Cultural Landscape in the Northern Adriatic at the Beginning of the Twentieth Century: The Case of the Verdi Monument in Trieste.] Acta Histriae, Vol. 23, No. 1, pp. 113-130. Available at http://zdjp.si/wp-content/uploads/2015/07/AH_232015-1_KLABJAN.pdf, last accessed on 23 January 2018.

Ličen, Daša 2017. Med cesarstvom, nacijo in nostalgičnimi vizijami? Postavljanje in odstavljanje spomenikov habsburškega Trsta. [Between Empire, Nation and Nostalgic Visions? Erecting and Removing Monuments of Habsburg Trieste.] Zgodovina za vse: vse za zgodovino, Vol. 24, No. 1, pp. 20-31.

Millo, Anna 2007. Trieste, 1830-70: From Cosmopolitanism to the Nation. In: Laurence Cole (ed.) Different Paths to the Nation: Regional and National Identities in Central Europe and Italy, 1830-70. New York: Palgrave Macmillan, pp. 60-81. DOI: $10.1057 / 9780230801424$.

Pickering, Michael \& Keightley, Emily 2006. The Modalities of Nostalgia. Current Sociology, Vol. 54, No. 6, pp. 919-941. http://dx.doi.org/10.1177/0011392106068458.

Sluga, Glenda 2001. The Problem of Trieste and the Italo-Yugoslav Border: Difference, Identity, and Sovereignty in Twentieth-Century Europe. New York: State University of New York.

Srinivas, Tulasi 2013 [1997]. "As Mother Made It": The Cosmopolitan Indian Family, "Authentic" Food, and the Construction of Cultural Utopia. In: Carole Counihan \& Penny Van Esterik (eds.) Food and Culture: A Reader. New York \& London: Routledge, pp. 355-375.

Sutton, David E. 2001. Remembrance of Repasts: An Anthropology of Food and Memory. London: Berg.

Verginella, Marta 2009. Meja drugih: Primorsko vprašanje in slovenski spomin. [The Border of the Others: The Question of Littoral Region and Slovenian Memory.] Ljubljana: Modrijan.

Verginella, Marta 2016. Dokončni boj med “severnojadranskimi rasami” v iredentističnem in fašističnem diskurzu. [The Final Struggle Between the "Northern Adriatic Races" in the Irredentist and Fascist Discourse.] Acta Histriae, Vol. 24, No. 4, pp. 705-720. Available at http://zdjp.si/wp-content/uploads/2017/01/AH_24-20164_VERGINELLA.pdf, last accessed on 23 January 2018.

Waley, Paul 2009. Introducing Trieste: A Cosmopolitan City? Social \& Cultural Geography, Vol. 10, No. 3, pp. 243-256. http://dx.doi.org/10.1080/14649360902756911.

Wolff, Larry 1994. Inventing Eastern Europe: The Map of Civilization on the Mind of the Enlightenment. Stanford, CA: Stanford University Press. 